\title{
Islam and Modernity---A Selective Influence of the Capitalistic Set-up
}

\author{
Dr. Sobia Tahir
}

\begin{abstract}
Modernity is a term referred to the complex trends of thought which led mankind to the present age with far reaching consequences. The socio-cultural milieu, we are living in, is, nonetheless, a product of modernity. Though as per experts and critics of the field, modernity ended by the beginning of the later half of the $20^{\text {th }}$ century and is no more relevant now. Currently the real topic to be discussed is post-modernity, which is also perhaps in the last phase(s). We, however, may not claim to be surviving in the post-modern era, because we are still at premodern stage of history especially in the context of Islam and the Muslim World. Hence, for us this topic still bears vital significance though outlived by the contemporary world.
\end{abstract}

Generally speaking, modernity started from the $17^{\text {th }}$ century and lasted till fourth decade of the $20^{\text {th }}$ century. It appeared as a markedly visible and dominant trend by $18^{\text {th }}$ century and Industrial Revolution of the $19^{\text {th }}$ century practically converted it into the 'Spirit of the Age'. It held this position firmly till World War II, which once again played havoc not only with human lives, but also with existing thinking patterns and left question marks on accepted wisdom and changed the intellectual perspectives of mankind.

Modernity brought with it a host of fresh ideas and new horizons to be explored which collectively influenced every aspect of life ranging from socio-political thought to cultural standards. No field of organized knowledge, be it Sociology, Psychology or Natural Sciences and Technology could escape its overwhelming effects. On the other hand, it conferred novel meanings on art, literature and allied disciplines, leading them to yet unexplored dimensions.

Among others, Liberalism, Democracy, Representative Government, Socialism, Industrialization, Urbanization, Healthcare, Child Survival, High Literacy, Mass Media and Sophisticated Weaponry are the direct products of modernity. Like every field of life, modernity impinged on religion too and brought noticeable changes in the outlook and methodology of religion itself. Modernity, no doubt appeared as the strongest challenge for the very existence of religion. The most radical idea launched by it was the separation of religion from state and political affairs. Hence it had to face tough resistance from every religion. Despite confrontation, every religion absorbed the effects of modernity in its specific manner. Islam is no exception.

The Muslim World, at the beginning, accepted modern thought with all its corollaries warmly, though cautiously. Why did it later turn to revivalism and fundamentalism? This has reasons to be explored beyond the scope of this study 
although we may briefly mention these. We may list a number of scholars in Iran, Turkey, Egypt, India and other parts of the globe who wholeheartedly desired and tried to bring Islam at par with modern trends. Sayyid Ahmad Khan, and Muhammad Iqbal from India, Jamal-al-Din-Afghani from Afghanistan, Ishak Efindi and Kudsi Efindi from Turkey, Mirza Malkom Khan from Iran, Mohammad Rashid Rida, Qasim Amin and Muhammad Abduh from Egypt are only a few amongst the large and brilliant galaxy. And, then who can forget the invaluable services of Indonesian Achmad Dachlan!

The zeal and fervor however, was dampened after WWI because of the fall of the Ottoman Empire and shift of the centre of power. This was the point where, according to some analysts, the Muslim World "lost faith in the culture of Science and Materialism." 151 This has been explained by Dr. Mohammad Khalid Masud in the following words:

".......This is probably because modernity came to be known in the Muslim world in the wake of colonialism when Muslims found themselves on the defensive. To the Western colonial regimes, Islam was not compatible with modernity and hence it was to be reformed or modernized or else marginalized. Muslims, therefore, generally conceived modernity, modernism and modernization not only as Western and alien but also hostile and threatening". ${ }^{152}$ Hence, the Muslim World has been struggling against modernity till today in one way or the other. (This will be elaborated in Part II of this paper). ${ }^{153}$ Similar views have been expressed by Francis Robinson in one of his essays on the topic. He writes:

"Muslim domination came to an end as Renaissance, Reformation, Enlightenment and Industrial Revolution transformed Europe from within. The first signs of changing power relationships came when on 12 September 1683 the Ottomans were forced to lift their siege of Vienna. Further defeats followed, and the tripping point came when in 1798 the French invaded Egypt and in 1799 the British defeated the forces of Tipu Sultan, the last significant Muslim Power in India. From this moment, Western power surged across the Muslim world with the British, the Russians, the French and the Dutch in the van. By 1920 almost the whole of Muslim world was under Western rule or powerful Western influence. The only areas free from it were North Yemen, Central Arabia and Afghanistan" ${ }^{154}$.

Iftikhar H. Malik, an eminent scholar of the contemporary Muslim scenario, agrees with the above quoted thinkers. In his recent work, Islam and modernity: Muslims in Europe and the United States, he writes:

"Muslims have usually accepted modernity, though not always willingly, and, in several cases, the haphazard nature of modernising efforts has increased anxieties and tensions, generating violent and fundamentalist reaction. In some cases,

\footnotetext{
${ }^{151}$ Peter Watson, Modern Mind: An Intellectual History of the $20^{\text {th }}$ Century (New York: HarperCollins, 2001), 1096.

152 Muhammad Khalid Masud, “ Iqbal's Approach to Islamic Theology of Modernity",(Paper presented in Iqbal Memorial Lecture organized by the Department of Philosophy, University of the Punjab, Lahore, April 10, 2008).

${ }^{153}$ See P. 11 below.

${ }^{154}$ Francis Robinson, “Islam and Modernities”, Pakistan Vision 8, no. 2 ( 2008): 2.
} 
modernising yet non-representative regimes have themselves coopted and promoted fundamentalist reaction ${ }^{155}$."

(This point will be discussed in Part II of this paper) ${ }^{156}$.

The Muslim world has a selective approach towards the issue which is the focal point of this paper. The Muslim intelligentsia appreciated some aspects of modernity according to their own taste, intellectual orientations and interests too. Therefore, we find a sort of perplexity and confusion throughout the Muslim world with numerous brands of Islam. Today's Islam is doubly divided; on the basis of sects and due to piecemeal and fragmentary adoption of some characteristics of modernity and rejecting their other related features and logical consequences.

In support of the above assertion, I would like to quote an example from Iqbal. He, in the first lecture of his famous collection, 'The Reconstruction of Religious Thought in Islam', highlighted the importance of fresh interpretation of faith in the light of Modern Physics in the following words, "With the advance of scientific thought even our concept of intelligibility is undergoing a change. The theory of Einstein has brought a new vision of the universe and suggests new ways of looking at problems common to both religion and philosophy. No wonder that the younger generation of Islam in Asia and Africa demands a fresh orientation of their faith. With the reawakening of Islam, therefore, it is necessary to examine, in an independent spirit, what Europe has brought and how far the conclusion reached by her can help us in the revision and, if necessary, reconstruction of theological thought in Islam." ${ }^{, 157}$ However, the same Iqbal who has been so fond of modernity that he was keen to reinterpret the tenets of religion with the help of Einstein, ${ }^{158}$ appears as a staunch opponent of modernity when the allied issues raise their head. These are definitely interlinked and can be solved only with the help of modernity alone.

Industrialization and rise of capitalism made the problem of Muslim identity more acute and serious. It was not possible for the Muslim World to escape both but again Muslim thinkers detested the inter-linked change with various tools for various reasons. For instance, Natini Natranjan is of the opinion that Iqbal was critical of colonial and capitalistic modernity. He turned to Islamic tradition for the critique of colonial modernity and in search of alternative modernity. ${ }^{159}$ (Italics by the author).

This tension between Islam and modernity was at its peak in the subcontinent during the first half of the $20^{\text {th }}$ century. The tussle was most pronounced and visible

155 Iftikhar H. Malik, Islam and Modernity: Muslims in Europe and the United States (London: Pluto Press, 2004), 1.

${ }^{156}$ See P. 11 below.

157 Allama Muhammad Iqbal, The Reconstruction of Religious Thought in Islam (Lahore: Institute of Islamic Culture, 2006), 6.

${ }^{158}$ Einstein was not a religious thinker, nor does Physics deal with theological subjects. (Author)

${ }_{159}$ Natini Natranjan, (ed.) Handbook of Twentieth Century Literature (Westport CT: Greenwood Press, 1996), 337. 
in the field of education. In this connection, Fazlur Rahman's revealing observations will make a valuable reading:

"A further complicating factor was that this new education has been transplanted from another living organism in Europe, with its own cultural background and its own internal structure and consistency. Although this had happened earlier to Islam with the influx of Greek Philosophy and science.............., but the Islamic civilization confronted modern Western Sciences at a multiple disadvantage---psychological as well as intellectual---because of the political domination, economic aggression, and intellectual hegemony of the West............Both the old and the new types of education suffered from the absence of mutual integration, but the new one was damaged most, at least in the short run. Because of its foreign provenance and lack of roots in the new culture, the new education had its harmful effects for several generations................... Sayyiad Ahmad Khan himself described the early products of Aligarh as "Satans". As for their lack of originality and usefulness to their societies, this idea was strongly expressed by Hali, Shibli Nu'mani and Iqbal. The derogatory term maghrib zada (west-stricken) was applied to the modern educated and Westernized classes by many writers, the most prominent of them being Azad, Zafar Ali Khan and Mawdudi" ${ }^{160}$.

Every such controversy, in some form or the other, does lead to clash of economic interests and class-conflict. This aspect of Islam vs. Modernity in the field of education has been beautifully analyzed by Javed Majeed in his enlightening essay, "Nature, Hyperbole and Colonial State, Some Muslim Appropriations of European Modernity in Late Nineteenth Century Urdu Literature". Following is a relevant quote from the same, strengthening the observations presented above:

" Broadly speaking, the Aligarh movement represented the interests of an Urduspeaking elite and of Muslim service gentry in late nineteenth century India......The prime mover behind the Aligarh movement was Sayyid Ahmad Khan..........Sayyid Ahmad Khan was also a key figure in defining what has been called, 'Islamic Modernism' in India" 161 .

Due to these area-specific internal differences and disagreements in the Muslim World, the emphasis was laid on modeling 'alternatives' of modernity

160 Fazlur Rahman, Islam and Modernity: Transformation of an Intellectual Tradition (Chicago \& London, The University of Chicago Press: 1984), 71-72.

${ }^{161}$ Islam and Modernity: Muslim Intellectuals Respond, ed., John Cooper, Mohamad Mahmoud, Ronald Nettler (New York \& London: I.B. Taurus and Company, 2000), 10.

This is a fine book on the topic with six highly academic essays, interested readers may like to see the following too:

i) "The limits of the Sacred: The Epistemology of Abdul Karim Soroush", John Cooper;

ii) "Mahmud Muhammad Taha's Second Message to Islam and his Modernist Project", Mohamad Mahmoud;

iii) "Mohamed Talibi's Ideas on Islam and Politics: a Conception of Islam for the Modern World", Ronald L. Nettler;

iv) "Islamic History, Islamic Identity and the Reform of Islamic Law: The Thought of Husayn Ahmad Amin", Nadia Abu -Zahra 
.Unfortunately these alternatives were neither strictly Islamic in spirit nor truly modern.

The same treatment was meted out to capitalism by the Muslim intelligentsia, their masses and governments. The rise of capitalism was the most important feature of modernity which influenced its future course of action decisively. Capitalism had/has its pros and cons like any other system. It is perhaps the most misinterpreted system with a negative connotation and unpleasant undertones. It is considered a symbol of reaction and synonym of exploitation. It is often said that religion provides a cover and protection to this system.

In the later half of the present paper, we would critically examine these issues in the context of Islam. However, at the beginning, we would discuss the role of capitalism in shaping modernity along with political, social, economic and cultural repercussions.

\section{I}

\section{What is Capitalism?}

\section{Growth and Evolution of Capitalism and its Implications}

The Roman Empire is considered the birthplace and hometown of capitalism. With the growth of the Roman Empire, the capitalistic economy also flourished in Europe. However, with the collapse of the Empire, mercantilism was almost replaced by feudalism in Europe, while the former managed to survive in Arabia by the $6^{\text {th }}$ century. The $7^{\text {th }}$ century brought with it the advent of Islam, with which mercantilism once again expanded itself to Europe, Asia and Africa as the far off lands came under the influence of Islam very soon. Abraham L. Udovich has mentioned in his work, "Partnership and profit in Medieval Islam" that merchant capitalism was founded by Muslim/Arab traders during the $9^{\text {th }}-12^{\text {th }}$ centuries. The monetary system established was based on a strong and stable currency, that is, Dinar, carrying a high value. This monetary market economy introduced these concepts which are still in vogue, such as, 'limited partnership (mudaraba), and 'partnership' (mufawada). The allied and relatively advanced concepts of credit, profit, capital (al-mal) and accumulated profit (Nama al-mal) were transported to medieval Europe from $13^{\text {th }}$ century onwards through Arabs. ${ }^{162}$

The passage below explains this point in regard to history and inter-linkage of mercantilism, capitalism and spread of Islam: "the medieval Europeans essentially learned mercantilism from their Islamic neighbors, evidenced in large part by a number of economic terms in European languages, that are derived from Arabic, such as 'tariff' and 'traffic'. From 1300's, Europeans would begin expanding their mercantile practices, resulting in social mobility hitherto unknown in European culture as well as in pushing Europeans as it did the Muslims, to explore distant

\footnotetext{
${ }^{162}$ Maya Shatzmiller, Labour in the Medieval Islamic World (Leiden: Brill Publishers, 1994), 402-403. See also: Jarius Banaji "Islam, the Mediterranean and Rise of Capitalism", Journal of Historical Materialism, (2007): 47-74.

Subhi Y. Labib, “Capitalism in Medieval Islam”, The Journal of Islamic History (1969), 79-96.
} 
parts of the globe. The voyages of discovery were entirely driven by mercantile ambition." 163

Capitalism passed through several phases and stages before reaching its present form. All of these may not be covered here in detail due to limited space. However, these include commercialism, monopolism, industrialization and globalization. The last two bear a special significance not only for capitalism but also for the history of mankind. Industrial Revolution of $18^{\text {th }}$ and $19^{\text {th }}$ centuries, according to The Concise Encyclopedia of Economics, literally revolutionized human life; it is one of the major developments of the recorded human history. It is the 'machine' that has not only transformed the production but also the environment, institutions, relations, outlook, philosophy, science, culture, almost every thing under the sun. The scientific advancement brought comfort, health, long life and prosperity with it, but on the other hand it 'gifted' humanity with imperialism, colonial rule, new modes of slavery and subjugation, horrific wars, deadly weapons and innumerable other curses. The Industrial Revolution provided capitalism with wings with whose help it invaded the entire world with unmatched speed. The inventions of postindustrial age converted the world into wonderland. The logical corollary of such scientific advancement, break through in communication and transportation is definitely globalization. Some thinkers consider globalization as prolongation of imperialism. It can be argued that globalization which is a purely $20^{\text {th }}$ century product has reduced the world to a small village with fast modes of traveling, online transactions and latest information technology. Globalization has brought with itself new modes of exploitation, social, cultural, political challenges and novel forms of identity crises. This we would discuss in the next section on selective influence and choice of Islam in the capitalistic set-up.

However, before moving ahead, it would be quite relevant to study the political offshoots of capitalism. The political institutions in any form around us are direct outcome of capitalism. There is nothing wrong in this seemingly sweeping statement. For a long time the world has remained divided in two poles or camps along with its entire set-up, that is, capitalistic and counter capitalistic.

Capitalism, though fundamentally an economic system, has given birth to a number of liberal political movements and institutions based on individual liberty and rights including that of private property. History tells us that economic stability is ambitious enough and always strives for political power. Political power, in turn, desires expansion and assumes the role of imperialism. Actually these are economic interests that hide themselves under the garb of political outfits. We would discuss this aspect before going ahead.

The Age of Enlightenment in fact is marked by the rise of two phenomena, i.e. Capitalism and Liberalism. Some theoreticians do not see any relationship between the two and just consider it an example of a non-concomitant occurrence. However, it has been debated on strong arguments that both are not only interrelated, rather capitalism is a fore-runner of liberalism, as the latter insists on individual liberty, rights and opportunities. Among the most prominent thinkers and theorizers of the

\footnotetext{
${ }^{163}$ The European Enlightenment Glossary, "Capitalism".

http://www.wsu.edu./---dee/GLOSSARY/CAPITAL.HTM
} 
Age of Enlightenment, it was John Locke who first of all spoke for State of Nature, Natural Law, Social Contract, and Rights of Man including Right to Private Property. Bertrand Russell, in his famous History of Western Philosophy has written about Locke, capitalism and liberalism, “.............. That is to say, men should be prudent. Emphasis on prudence is characteristic of liberalism. It is connected with the rise of capitalism, for the prudent became rich while the imprudent became or remained poor" ${ }^{\prime 164}$.

Locke defined political power in the following words, "Political power I take to be the right of making laws, with penalty of death, and consequently all less penalties for the regulating and preserving of property, and of employing the force of community in the execution of such laws, and in the defence of the commonwealth from foreign injury, and all this only for the public good"165. Property is very prominent in Locke's Political Philosophy, and is, according to him, the chief reason for institution of civil government: "The great and chief aim of men uniting into commonwealths, and putting themselves under government, is the preservation of their property; to which in the state of nature there are many things wanting". ${ }^{166}$ He further asserts that, "The supreme power cannot take from any man any part of his property without his own consent". ${ }^{167}$

The related ideas of liberalism are: political freedom, individualism, laissez-faire, liberal democracy, open society, mixed economy and market economy. Besides Locke, its chief exponents include Adam Smith, Thomas Malthus, Jeremy Bentham, John Stuart Mill, Thomas Hill Green, Alfred Marshall, John Maynard Keynes, Ludwig Von Mises, Freidrich Von Haykes, Milton Friedman, Robert Nozick and John Rawls.

Liberalism has many shades and nuances and has been broadly sub-divided into Classical, Social and Modern. We would however, confine our discussion to the last named which flourished in the Age of Enlightenment and rejected a number of in-vogue and prevalent concepts such as, i)Divine Rights of the Kings, ii) Hereditary Status of the Kings, iii) Established Religion, iv) Foundational Principles and v) Protectionism. The modern liberals advocated free market economy. These subjects will be discussed in detail with reference to Islam a little later.

All these brands of liberalism however have a consensus on freedom of thought, belief, action and speech. All these principles invariably lead towards the rule of law, transparent system of government based on open and free elections with complete equality among the citizens. Perhaps we are all familiar with this system called 'Liberal Democracy'. The gradual evolution of liberalism from capitalism and representative dispensation from liberalism is, nonetheless, inevitable. All the rights envisaged by liberalism may be secured only through this system of government. This point has been emphasized in the Oxford Manifesto of Liberal International in the following words, "These rights and conditions may be secured

\footnotetext{
${ }^{164}$ Bertrand Russell, History of Western Philosophy (London: George Allen \& Unwin Ltd., 1979), 593.

${ }^{165}$ Ibid.,607

${ }^{166}$ Ibid., 604

${ }^{167}$ Ibid., 609
} 
through true democracy. True democracy is inseparable from political liberty and is based on the conscious, free, and enlightened consent of the majority, expressed through a free and secret ballot, with due respect for the liberties and opinions of minorities".

However, like any other system, capitalism is not without inherent flaws due to which it has been criticized in all ages by religious and non-religious circles alike. It is considered a source of exploitation and monopoly, wars, unrest, strife and many other evils of socio-political life. Its most loathsome feature is interest or usury, condemned by all religions, especially Islam. Its prominent critics include Karl Marx, Friedrich Engels, Lenin, Mao Zedong, Leon Trotsky, Pierre-Joseph Proudhon, Rosa Luxemburg and amongst the contemporary thinkers Naom Chomsky. Globalization has further added to the strong critics of capitalism. Even liberalism and democracy have their opponents.

After this introduction of modernity, capitalism, liberalism and democracy, it is time to switch over to Islam and to examine Islam's original standpoint about all these and subsequent attitude/reaction regarding these trends and movements.

\section{II}

\section{Muslim World's Response --- A Selective Assimilation}

Islam being the last great monotheistic religion of the Semitic chain has a very broad, deep and comprehensive set-up of its own. To a large number of its believers, it is not a religion in ordinary sense of the word; not a collection of rites and rituals only but a complete code of life. It is wide enough to cover all the aspects of life. It is a SYSTEM. Now what is a system, it is an intricate complex of all-inclusive and clear-cut rules and regulations regarding all fields of life; from dietary principles to family laws, from social norms to cultural ideals, and, from political models to economic guidelines. And this structure is organized, well-built, fixed and inflexible.

To some experts on the other hand, Islam is not a hard and fast system; it is an ethical code only that provides mankind with some axioms and guiding principles. It is flexible enough and has room for picking and lifting, adjustment and adaptability. According to this school of thought, Islam is capable of absorbing and accommodating modern trends without any undue friction. These groups within the framework of Islam are known as fundamentalists and liberals respectively. However, there are a number of internal rifts and contradiction in both. As there is no categorical consensus on what Islam actually is, the phrase chosen for this paper is 'Muslim World' rather than Islam. The various brands of Islam with which we are familiar are definitely not true Islam, but they, nonetheless, are the representative shades and hues of Muslim opinion and mode of action.

This paper intends to show that Muslim World (not Islam) partly accepted modernity and partly resisted it. Its attitude remained selective. This selection, however, was based on the interests of the ruling classes. Unfortunately, Muslim world always remained in the iron grip of dictators, who manipulated Islam according to their own whims and desires. Same is the case with capitalism. Being an economic system, it was welcomed by the ruling elite as it provides room for private property and unlimited accumulation of wealth. For this purpose again, 
Scripture was interpreted 'selectively'. In our own times, Islam was used as a synonym of capitalism, so much so that the proxy war of capitalist bloc against former USSR was fought in the name of Islam; while communism stood as a synonym of atheism.

Though going too far for the promotion and support of capitalism, the Muslim World assimilated it only partly and strongly rejected its logically necessary derivatives, that is, Liberalism and Democracy. As a consequence, despite large human and natural resources, the Muslim World is still groaning under extreme poverty, rigid conservatism and worst dictatorship. This selective rather vestedinterests-based approach has practically kept Muslim World at a pre-modern level till today and earned a negative impression for Islam as an opponent of modernity and incompatible with the liberal tradition and democracy.

To exploit capitalism for keeping the masses deprived and backward, certain Qur'anic concepts were specifically highlighted and brought into prominence, for instance, fate (taqdeer) and promised or pre-ordained subsistence (rizq-e-mauood). Since poor and illiterate people may be easily shackled into the yoke of dictatorship, hence for the very purpose, it is essential to suppress liberal thought and education as far as possible. The above mentioned concepts may serve competently to justify poverty, thus promoting backwardness and illiteracy.

Let us briefly look at the capitalistic orientations of Islam. As far as sustenance is concerned, it is categorically stated in the Quran that Allah is responsible for provision of food for every living organism. For instance, the Quran says: "There is no creature that moves in the earth but it is for Allah to provide it with sustenance. And He knows its lodging and its home. All (this is recorded) in a clear Book" "168

The Quranic verse established two things: i) Sustenance is promised (mauood) by Allah, ii) Sustenance in either quantity is pre-determined (muqaddar) by Allah, as it has already been written in the Divine Record. This idea has been persistently exploited not by upholders of capitalism as such but by those who want to justify unequal or unfair distribution of resources. Another relevant verse follows as, "..........and that you kill not your children for (fear of) poverty--- it is We Who provide you for and for them....." ${ }^{169}$ (It is one of the verses quoted frequently by opponents of family planning and birth control). At times Allah provides you from where you do not expect, "And will provide for him from where he expects not". ${ }^{170}$

At different places, the Qur'an rationalizes the economic disparities and inequalities in human society. For instance, "Is it they who distribute the mercy of thy Lord? It is We, Who distribute their livelihood in the present life, and We exalt some of them above others in degrees (of rank) so that some of them may make others subservient (to themselves). And the mercy of thy Lord is better than that which they amass". ${ }^{171}$ Another verse reads, "And Allah has favored some of you above others in sustenance. But those who are more favored will not restore (any

\footnotetext{
${ }^{168}$ Al-Qur'an, 11: 7.

${ }^{169}$ Ibid., 6: 152.

${ }^{170}$ Ibid., 65:4.

${ }^{171}$ Ibid., 43: 33 .
} 
part of their worldly) gifts to whom their right hand possesses, so that they may be equal (sharers) in them. Will they then deny the favor of Allah"? ${ }^{172}$

Lest it is misunderstood, this paper does not aim at portraying Islam as an instrument of reaction or exploitation. What is being argued is that Islam is through and through capitalistic in its economic approach, and has not stressed on equal distribution of resources. However, it lays emphasis on charity and sympathy for the under-privileged again and again as will be discussed later. The underlying principle of Zakat is of taking wealth from the rich and giving it to the poor. One of its functions is to purify the money being utilized by the rich. However, eradicating poverty is not the Divine design, because classes have been produced by Allah Himself through uneven distribution of sustenance. Allah gives to some without measurement and to some He gives in small measured quantities as is evident from the following verses.

“........Allah bestows sustenance on whomsoever $\mathrm{He}$ pleases without reckoning" ${ }^{\prime 173}$.

“.........Surely Allah gives to whomsoever He pleases without measure". ${ }^{174}$

".........Allah does provide whomsoever He pleases without measure" 175

"Allah enlarges provisions for whomsoever $\mathrm{He}$ pleases and straitens (it for whomsoever He pleases)". ${ }^{176}$

"Surely thy Lord enlarges provisions for whomsoever He pleases and straitens (it for whomsoever He pleases)". ${ }^{177}$

"..........It is indeed Allah Who enlarges the provision for such of His servants as He pleases and straitens it (for whom He pleases)". ${ }^{178}$

"Allah enlarges (the means of) sustenance for such of His servants as He pleases and straitens (them) for whom (He pleases). Surely Allah has full knowledge of all thing". 179

${ }^{172}$ Ibid., 16:72.

These verses were extensively quoted by Islamic political parties of Pakistan against Z.A. Bhutto when he adopted Socialism as economic system of Pakistan in early 1970s. Socialism was painted as atheistic because it rebelled against 'divine disparities' and opted for equality not ordained by Islam. Later this argument was developed to its logical limits and culminated in overthrow of Bhutto regime through a reactionary religious movement in 1977, subsequent Afghan Jihad in 80s and dissolution of Soviet Russia in 1991.

${ }^{173}$ Ibid., 2:213.

174 Ibid., 3:38.

${ }^{175}$ Ibid., 24:39.

${ }^{176}$ Ibid., 13:27.

${ }^{177}$ Ibid., 17:31.

${ }^{178}$ Ibid., 28:83.

${ }^{179}$ Ibid., 29: 63. 
"Have not they seen that Allah enlarges His provision to whomsoever He pleases, and straitens (it to whomsoever He pleases)? In that truly are the Signs for those who believe" 180 .

"Say verily my Lord enlarges the provision for (whomsoever) He pleases, and straitens (it for whomsoever he pleases); but most men do not know". ${ }^{18}$

"Say, 'Surely my Lord enlarges the provision of such of His servants He pleases and straitens (it) for such of them as (He pleases). And whatever you spend, he will replace it; and He is the best of Providers".

"Know they not that Allah enlarges the provision for whomsoever He pleases and straitens (it to whomsoever He pleases)? Verily, in that are the Signs for a people who believe". 183

"To Him belong the keys to the heavens and the earth. He enlarges the provision to whomsoever He pleases, and straitens (it to whomsoever He pleases). Surely He knows all things full well". ${ }^{184}$

"Allah is Benignant to His servants. He provides for whom He pleases. And He is the Powerful, the Mighty". ${ }^{18}$

"And if Allah should enlarge the provision for His servants, they would rebel in the earth; but He sends down according to a (proper) measure as He pleases. Indeed He is All-Aware and All-seeing with regard to His servants". ${ }^{186}$

In the face of the abundant evidence above, there is no doubt that economic inequality is part of the Divine scheme and sustenance is measured and predetermined for every soul by the sweet will of the Lord. However, since Allah has to fulfill His promise of provision, the rich are enjoined to give charity to their less fortunate brethren. This will purify their wealth; otherwise they will have to burn in the hellfire eternally. Moreover, those whose sustenance has been straitened are exempt from many religious duties with pecuniary implications. The following verse explains this: "Let him who has abundance of means spend out of his abundance. And let him whose means of subsistence are straitened spend out of what Allah has given him. Allah burdens not any soul beyond what He has given him, Allah will soon bring forward ease after hardship". ${ }^{187}$

This is known as 'trickle down' or 'spin off' effect in modern capitalistic economics of which the roots and foundations may be traced within Islam. Hence the capitalistic nature of Islam is established beyond any reasonable doubt.

In support of the above assertions, following contention of Syed Abu Ala Maudoodi is most relevant:: "The economic scheme presented in Qur'an is based

\footnotetext{
${ }^{180}$ Ibid., 30: 38.

${ }^{181}$ Ibid.,34:37.

${ }^{182}$ Ibid., $34: 40$.

${ }^{183}$ Ibid., 39:53.

${ }^{184}$ Ibid., 42:13.

${ }^{185}$ Ibid., 42:20.

${ }^{186}$ Ibid., 42:28.

${ }^{187}$ Ibid., 65:8.
} 
entirely on the idea of individual ownership in every field.......The mere fact that it mentions in one place that "the earth belongs to God $(7: 129)$ " is not enough to conclude that it either denies or forbids private ownership of land and sanctions nationalization." 188

He goes on to say, "It is equally erroneous to draw from verse xIi, 10 the inference that Qur'an desires to distribute all the means of livelihood in the earth equally among all men..........For the purpose of this interpretation the verse is wrongly rendered to mean that 'God has put in the earth its means of sustenance proportionately in four days, alike for those who seek'. But even this wrong translation does not serve the purpose". ${ }^{189}$

" The fact that as in other things, all men do not enjoy equality in sustenance and means of earning, is described in the Qur'an as a feature of God's providence. Extravagant disparities devised by various social systems aside, natural inequality, as it goes, is described as the outcome of His wise apportionment, issuing from His own dispensation. The idea that this inequality is to be leveled up and substituted by dead equality is alien to the Book of God". ${ }^{190}$ Another verse of the Qur'an on this point reads, ".......And He it is Who has made you successors (of others) on the earth and has exalted some of you over others in degrees (of rank) , 191

Thus far, Islam is in complete harmony with capitalism. But same is the point of divergence where Islam comes in contrast with Western tradition of the same as well as modernity. And, this is the stage to show how Islam has selectively assimilated some aspects of modernity including capitalism and left the other. Unfortunately this selective attitude was /is basically a defensive shield and safeguard for the interest of the non-representative ruling classes and the reactionary forces. We have seen earlier that liberalism and democracy are logical corollaries of capitalism. These liberal and democratic traditions have flourished in the West and led to free, open, egalitarian and welfare oriented societies in spite of unequal distribution of resources and economic disparities. But this could not happen in the Muslim World and we know what treatment was meted out to liberal and democratic thought in the Muslim World. Till today, out of 57 independent Muslim states of the world, a vast majority is in the grip of monarchies or military dictators whereas some so-called democracies are also completely dependent on the West.

Here I would like to refer back to a statement made earlier in this paper which may now be read again in the light of above discussion:

“...... This is probably because modernity came to be known in the Muslim world in the wake of colonialism when Muslims found themselves on the defensive. To the Western colonial regimes Islam was not compatible with modernity and hence it was to be reformed or modernized or else marginalized. Muslims, therefore,

\footnotetext{
${ }^{188}$ Abul Ala Maudoodi, "Economic and Political Teachings of the Qur'an", in A History of Muslim Philosophy, vol. I, ed. M.M. Sharif (Karachi: Royal Book Company, 1983), 179.

${ }^{189}$ Ibid., 179.

190 Ibid., 180

${ }^{191}$ Al-Qur'an, 6: 166
} 
generally conceived modernity, modernism and modernization not only as Western and alien but also hostile and threatening". ${ }^{192}$

The reality is rather different and bitter, because Islam neither was, nor is incompatible with modernity, nor is modernity threatening, hostile or alien to Islam. Actually, modernity is hostile to the Muslim rulers' interests as are incompatible with the interests of Muslim masses. Hence to keep their people subjugated, submissive, compliant and docile, the elite have always propagated that modernity is incompatible with Islam. They accept such aspects of modernity including capitalism as serve their class interests but reject those as are pro-masses, and a very shrewd and opportunist intelligentsia has very successfully helped them in this selective approach. See the later part of the quote from Iftikhar H. Malik once again which reads, "In some cases modernising yet non-representative regimes have themselves coopted and promoted fundamentalist groups" ${ }^{\prime 193}$. Why? Because enlightened, liberal, modern and pro-masses thought does not suit them. Moderate intellectuals have never found favor with non-representative Muslim regimes. He goes on to say, ".........while issues of political marginalization, economic adversity and warfare in all Muslim regions continued to be ignored. The Muslim ruling elite-monarchs, dictators and pseudo-democrats--sat aloof, biding the time, while the fundamentalists offered a reductionist palliative to mundane hardships" 194 . He states categorically, "For example, on one hand, political Islam may stipulate resistance to western hegemony; but at the same time many of its current forms are equally totalitarian" ${ }^{, 195}$.

Fazlur Rahman in chapter 'Contemporary Modernism' of his famous book has analyzed these points more critically with much focused approach. He writes, "But in the situations where masses were ignorant and illiterate and a relatively small modern-educated elite claimed to be working on their behalf for their material prosperity, political freedoms were often curtailed both in "socialistic" and "liberal" countries, since the rulers felt that political games would thwart quick economic development and in some cases threaten the "security of the state".

" The salient features of this new situation from our present perspective are 1) that the governments of these countries, whether democracies or dictatorships, socialistoriented or "free-economy"-oriented, are largely self-styled brokers on behalf of their masses; 2) that the governments consider themselves agencies of development; 3 ) that by "development" is meant exclusively "economic progress"; ...........6) that the masses in these countries are uneducated, ignorant and extremely conservative..........there is, in this respect at least, hardly any effective communication between their broker governments and themselves. Finally and most important, 7) this political, social and moral situation is aggravated and made

\footnotetext{
192 See P. 2 above

193 See P. 2 above

194 Iftikhar H. Malik, Islam and Modernity: Muslims in Europe and the United States (London: Pluto Press, 1984), 4.

${ }^{195}$ Ibid.,5.
} 
far more pernicious by the extremely low priority given to education because of the myopic vision of progress as being purely material. ${ }^{196,}$

Thus, we see how Muslim regimes have been exploiting some principles of capitalism against liberalism and democracy quite in contrast with Western liberal democratic traditions. I slightly differ from Fazlur Rahman; the vision of Muslim governments is not "myopic", it is very sharp. They have deliberately kept their masses illiterate because an educated, enlightened and aware public is deadly to their own interests. This "far-sightedness" hidden in this agenda is to keep the masses backward in the field of education. The greatest evidence being that no university in the Muslim world falls in the first 500 advanced academic institutions of the world!!

As another interesting observation, communism had always been declared unIslamic because it ensured economic equality which is against Divine order! Thus, capitalism was accepted with great zeal but its off-shoots of liberalism and democracy were ruthlessly crushed as these did not suit Muslim regimes, hence incompatible with Islam.

Before concluding this study, it would be fruitful to have a short appraisal of the proposed political system of Islam in the words of Syed Maudoodi. The political system of Islam is generally known as Caliphate (vicegerency), which though not strictly democratic, is not as autocratic and authoritarian as depicted by the vestedinterests groups. The major rules of the Caliphate are as under:

a) All the powers that man possesses in this world are in fact not his own, but have been endowed on him by God Almighty...........Man is thus not an independent master but a vicegerent of the real Sovereign;

b) Every nation that acquires the power and authority to rule over any part of the world is in reality a vicegerent to God in its domain;

c) This vicegerency, however, cannot be rightful or lawful unless it is subservient to the commandments of the real Sovereign. Any state independent of Him and not subservient to His commands is not a vicegerency. It is really a revolt against the Lord. (Al-Qur'an, 24:55, 35:39);

d) The powers of a true Caliphate do not vest in any individual nor in any clan, class or community, but those who believe and do good. The text of xxiv, 55 that " God has promised to those of you who believe and do good that He will most certainly make them His vicegerent on the earth...." is quite clear on this point. According to this verse, every good Muslim is fit to hold the position of a caliph. It is this aspect of Islamic caliphate that distinguishes it from a kingship, oligarchy, and a theocracy. It is different even from a modern democracy. There is a basic difference between the two. The edifice of democracy is raised on the principle of popular sovereignty; while in Islamic caliphate the people themselves surrender their independence to the sovereignty of

196 Fazlur Rahman, Islam and Modernity: Transformation of an Intellectual Tradition (Chicago \& London: The University of Chicago Press, 1984). 88-89. 
God and of their own accord limit their power within the four corners of the Divine Law and the promise of vicegerency has been held out to them only if they are morally good. ${ }^{197}$

An oft quoted verse in Qur'an reveals Almighty Allah's sovereignty in regard to bestowing His caliphate upon any one He pleases. The verse reads as: "Say, 'O Allah, the Lord of Sovereignty, thou give sovereignty whomsoever Thou please; and Thou take away sovereignty from whomsoever Thou please. Thou exalt whomsoever Thou please and Thou abase whomsoever Thou please. In Thy hand is all good. Thou surely have power to do all things."198 This is the most frequently used verse of the Qur'an by autocratic dictators, authoritarians and totalitarian Muslim rulers who usurp worldly power through fair and foul means and then declare it as the Divine Will..

Another misinterpreted verse is as follows, "O ye who believe! Obey Allah and obey the Apostle and those of you who are in authority..... ${ }^{199}$ This verse seems to give license to the ruling classes to demand absolute obedience from their subjects whereas the case is entirely different as is evident from this passage of Syed Maudoodi: "The government of a State established with a view to running an Islamic Caliphate cannot claim an absolute or unlimited obedience from the people. They are bound to obey it only in so far as it exercises its powers in accordance with the Divine Law revealed in nature and the Sacred Book. There can be neither obedience nor cooperation in sin and aggression" $(5: 3)^{200}$.

Moreover, the Caliphate is not a dictatorial institution as envisaged by those whom we call vested-interest groups. A number of eminent political thinkers and scholars such as Al-Mawardi , Abu-Yala and al-Baghdadi have spoken of elections by notables (Abu Bakar's case), designation by the incumbent (Umar's case), nomination by Electoral College (Uthman's case) and direct election by people (Ali's case) as valid forms of instituting a Khalifa. ${ }^{201}$

This proves that unfortunately, the Muslim World's attitude is selective not only towards modernity or capitalism but also towards Islam and the Qur'an.

\footnotetext{
197 Abul Ala Maudoodi, "Economic and Political Teachings of the Qur'an”, A History of Muslim Philosophy, Vol. I, ed. M.M. Sharif (Karachi: Royal Book Company, 1983), 193-94. ${ }^{198}$ Al-Qur'an, 3: 27.

${ }^{199}$ Ibid, 4:60.

${ }^{200}$ Abul Ala Maudoodi, "Economic and Political Teachings of the Qur'an", A History of Muslim Philosophy, Vol. I, ed. M.M. Sharif (Karachi: Royal Book Company,1983), 194.

${ }^{201}$ Dr. Mohammad Shah, Pan Islamism in India \& Bengal (Karachi: Royal Book Company, 2002), 21-22.
} 


\section{III}

\section{Conclusion}

The above analysis shows that the Muslim World has accepted modernity and its related features only spartly and partially. Of course, no trend, idea, scheme or plan can be accepted in toto and one has to tailor or adjust it to some extent. Therefore, if Islam has not fully embraced modernity, capitalism, liberalism or democracy, it is not a major objection per se. The problem lies with the selectors who have not made the selection pragmatically or in the larger interest of Islam as the sole criteria of their selection was to watch their personal and class interests. The autocratic Muslim rulers did not hesitate from arbitrary and out -of- context interpretations of Qur'an for their tendentious designs; liberalism and democracy being their worst targets. Muslim states rarely allowed/allow freedom of speech, opinion, belief and expression, equality of opportunity, gender equity, political rights, open society and individualism to their subjects (not citizens).

The Post World War I \& II situation, the decline of Turkey, lack of power, occupation of territories and resources robbed Muslim masses of their self-esteem and dignity, making their rulers heavily dependent on US and the West for support. This propaganda was supported, promoted and strengthened by the world powers that Islam is incompatible with modernity, liberal tradition and specially democracy.

The topic of this discussion precisely was Islam and capitalism. At the end, we can sum up by saying that: Islam is in perfect harmony with capitalism; rather its foundations and roots may be traced inside the earlier Islam. Hence there is no question of its rejection by Islam. However, most unfortunately, the Muslims watered capitalism very diligently and painstakingly as a nascent sapling but refused its ripe fruit in the form of the liberal outlook and representative democratic institutions. Islam accepted its waste and harmful by-products or one may say, least useful elements. This situation has led to the Muslim world to the situation where it stands today. Poverty, illiteracy and backwardness are its fate. Oil rich Gulf and Arab states are not poor, but, nonetheless, backward in technology and education besides being highly authoritarian.

In brief, it may be stated that the fault does not lie with Islam or with capitalism, it lies with the hopeless attitude of the Muslim World, specially its so-called leadership. 